\title{
EVALUATION OF AQUEOUS AND ETHANOLIC EXTRACTS OF SYZYGIUM CARYOPHYLLATUM FOR ANTIBACTERIAL ACTIVITIES
}

\section{RAGHUNATH PENDRU ${ }^{1}$, JAGAN NADIPELLY ${ }^{2}$, JYOTHINATH KOTHAPALLI ${ }^{3 *}$, SUBBANNAYYA KOTIGADDE $^{4}$}

${ }^{1}$ Department of Microbiology, School of Medicine, Texila American University, Guyana, South America. ${ }^{2}$ Department of Pharmacology, School of Medicine, Texila American University, Guyana, South America. ${ }^{3}$ Department of Anatomy, Maheshwara Medical College and Hospital, Chitkul, Isnapur, Patancheru, Telangana. ${ }^{4}$ Department of Microbiology, K.V.G Medical College and Hospital, Sullia, Karnataka. Email: kjyothinath@gmail.com

Received: 27 July 2017, Revised and Accepted: 16 September 2017

\section{ABSTRACT}

Objective: It has been well documented that traditional medicinal plants confer considerable antimicrobial activity against various microorganisms

Methods: The present study was designed to evaluate the antimicrobial properties of aqueous and ethanolic extracts of the leaves of Syzygium caryophyllatum against Staphylococcus aureus, Escherichia coli, Salmonella typhi, Shigella flexneri, and Vibrio cholerae. The aqueous extract was prepared using cold percolation method, and ethanolic extract was prepared in Soxhlet apparatus using ethyl alcohol. Antimicrobial activity is being determined by time-kill assay and minimum inhibitory concentration.

Results: From our study, it is found that all tested organisms were sensitive to both aqueous and ethanolic extract of leaves of $S$. caryophyllatum. The ethanolic extract showed better antibacterial activity against $S$. aureus and $S$. typhi when compare to aqueous extract. The phytochemical analysis confirmed the presence of flavonoids, alkaloids, glycosides, steroids, phenols, tannins, and saponins in the ethanolic and aqueous extract of S. caryophyllatum

Conclusion: We hypothesize that these active phytoconstitutents might be responsible for the antimicrobial activity of this plant.

Keywords: Syzygium caryophyllatum, Antimicrobial property, Time-kill assay, Minimum inhibitory concentration.

(C) 2018 The Authors. Published by Innovare Academic Sciences Pvt Ltd. This is an open access article under the CC BY license (http://creativecommons. org/licenses/by/4. 0/) DOI: http://dx.doi.org/10.22159/ajpcr.2018.v11i2.21687

\section{INTRODUCTION}

Syzygium caryophyllatum commonly known as wild black plum, a medium sized tropical evergreen tree belongs to the family Myrtaceae. The vernacular name of this plant is Jangli jamun in Hindi, Kattunjara, Kani pazham or Jnana pazham in Malayalam, and Kunta nerale in Kannada. S. caryophyllatum is native to India and Sri Lanka; in India, the distribution mainly occurs in the forests of Western Ghats. Tree grows along margin of evergreen forests or in open formations from low to higher elevations. Fruits are edible, sweet and astringent in taste and they are useful in stomatitis and intestinal disorder. The seeds and bark were dried, and its decoction was used for the treatment of diabetes mellitus [1]. The leaf and bark extracts of this plant are well known for its antibacterial and antioxidant efficacy [2]. Tribal peoples were considering this plant as a boon of nature, and its fruits and seeds were consumed by Paniya tribal community of Wayanad district, Kerala [3]. The hot extract of the leaves of this plant is consumed with milk as a remedy for mouth ulcers by rural people in this area. Leaf extracts of this plant also used locally to treat boils, external ulcers and sores [4]. Earlier studies revealed the above pharmacological properties of $S$. caryophyllatum. However, no study was done on its antibacterial activity. Therefore, the present study has been designed to investigate the antibacterial activity of aqueous and ethanolic extracts of $S$. caryophyllatum.

\section{METHODS}

\section{Preparation of extract}

The $S$. caryophyllatum leaves were collected, shade dried and made into fine powder and was shade dried, powdered. The aqueous extract was prepared using cold percolation method, and ethanolic extract was prepared in Soxhlet apparatus using ethyl alcohol [5].
Phytochemical screening

The ethanolic and aqueous extract of $S$. caryophyllatum leaves were subjected to qualitative chemical investigation for the identification of phytoconstituents [6] such as flavonoids, alkaloids, glycosides, steroids, phenols, tannins, and saponins. The extracts were treated with dilute hydrochloric acid ( $\mathrm{HCl})$ and filtered. The filtrate is used in the following tests.

Test for alkaloids (Mayer's test)

The extract filtrates were treated with Mayer's reagent, and the appearance of cream color indicates the presence of alkaloid.

\section{Test for tannins}

The extract filtrates were treated with $10 \%$ lead acetate solution; appearance of white precipitate indicates the presence of tannins.

Test for flavonoids (Shinoda test)

To the extract filtrates, add $5 \mathrm{ml} \mathrm{95 \%} \mathrm{ethanol,} \mathrm{few} \mathrm{drops} \mathrm{of} \mathrm{conc.} \mathrm{HCl}$ and $0.5 \mathrm{~g}$ magnesium turnings. Pink coloration indicates the presence of flavonoids.

\section{Test for saponins (froth test)}

About $1 \mathrm{ml}$ of the extracts were diluted to $20 \mathrm{ml}$ with distilled water and shaken well in a test tube. The formation of foam in the upper part of the test tube indicates the presence of saponins.

Test for terpenoids (Salkowski test)

About $5 \mathrm{ml}$ of extracts were mixed in $2 \mathrm{ml}$ of chloroform, and concentrated sulfuric acid ( $3 \mathrm{ml}$ ) was carefully added to form a layer. A reddish brown coloration of the interface was formed to show positive results for the presence of terpenoids. 
Test for carbohydrates (Molisch's test)

The extracts were treated with $3 \mathrm{ml}$ of alpha-naphthol in alcohol and concentrated sulfuric acid was added along the sides of the test tube carefully. Formation of the violet color ring at the junction of two liquids indicates the presence of carbohydrates.

Test for glycosides (modified Borntrager's test)

To $5 \mathrm{ml}$ of extracts $5 \mathrm{ml}$ of $5 \%$ ferric chloride and $5 \mathrm{ml}$ dil. $\mathrm{HCl}$ were added heat for $5 \mathrm{~min}$ in boiling water bath. Cool and add benzene or any organic solvent shake well. Separate the organic layer and add an equal volume of diluted ammonia. In the positive test, ammonical layer shows pinkish red color

\section{Determination of minimum inhibitory concentration (MIC)}

The MIC was determined using the agar dilution method [7]. The extracts were diluted such that the highest concentration of the solvent in agar was 5\% (predetermined to have no inhibitory effect on the test organism). Plates were inoculated with overnight broth cultures of the test organisms diluted 1:100 with fresh sterile nutrient broth and incubated for $18 \mathrm{~h}$ at $37^{\circ} \mathrm{C}$. The MIC was taken at the highest dilution (least concentration) of extracts showing no visible growth of the test organism.

\section{Time-kill assay (TKA)}

Determination of the rate of kill of the extracts was done following the procedure described by Okoli and Iroegbu [8]. Inocula were prepared following the described guidelines of EUCAST [9]. The resultant suspension was diluted 1:100 with fresh sterile broth and used to inoculate $50 \mathrm{ml}$ volumes of Mueller-Hinton broth incorporated with extract at MIC and 2× MIC to a final cell density of approximately $5 \times 10^{5} \mathrm{cfu} / \mathrm{ml}$. The flasks were incubated at $37^{\circ} \mathrm{C}$ on an orbital shaker at $120 \mathrm{rpm}$. A $500 \mu \mathrm{l}$ sample was removed from cultures at 0,6 , and $12 \mathrm{~h}$, diluted serially and $100 \mu \mathrm{l}$ of the diluted samples were plated on Mueller-Hinton agar plates and incubated at $37^{\circ} \mathrm{C}$ for $24 \mathrm{~h}$. Controls included extracts free Mueller-Hinton broth seeded with the test inoculum.

\section{RESULTS AND DISCUSSIONS}

Numerous antimicrobial drugs available in the market to treat various bacterial infections, however, still there is no promising drug therapy without side effects. In recent years, many traditional medicinal plants were tested for their antimicrobial potential. Although some of these plants have a great reputation in the indigenous system of medicine for their antimicrobial activities, many remain to be scientifically established. In the light of the beneficial effect of $S$. caryophyllatum, we made an attempt to study the antimicrobial effect of an ethanolic and aqueous extract of S. caryophyllatum leaves using two standard methods; these include MIC and TKA assay.

Gentamicin was used as a positive control on the tested bacteria in this study. Gentamicin had shown inhibitory effects on all the tested bacteria. However, the lowest MIC values $(0.005 \mathrm{mg} / \mathrm{ml}$ and $0.007 \mathrm{mg} / \mathrm{ml}$ ) of gentamicin were recorded against Escherichia coli (ATCC 25922) and Shigella flexneri (ATCC 12022) (Table 1). The highest MIC value $(0.020 \mathrm{mg} / \mathrm{ml})$ of gentamicin was recorded against Vibrio cholerae ATCC 39315. Both the extracts of $S$. caryophyllatum have shown good antimicrobial activity. However, remarkable activity was observed only with ethanolic extract of $S$. caryophyllatum. The ethanolic extracts have shown low MIC $(0.075 \mathrm{mg} / \mathrm{ml})$ against Salmonella typhi (ATCC 12225) and V. cholera (ATCC 39315).

In the TKA, both the aqueous and ethanolic extracts of $S$. caryophyllatum were able to kill all the tested bacteria after $2 \mathrm{~h}$ of treatment (Table 1). However, both the extracts were more active against Staphylococcus aureus ATCC 25923 when compared to other bacteria. Ethanolic extract was more active against $S$. typhi ATCC 12225 compared to aqueous extract (Table 1).
Table 1: Antibacterial activity of aqueous and ethanolic extracts of $S$. caryophyllatum

\begin{tabular}{llllll}
\hline \multirow{2}{*}{ Bacteria } & \multicolumn{5}{l}{ TKA (h) MIC (mg/ml) } \\
\cline { 2 - 6 } & aq & et & aq & et & Gentamicin \\
\hline S. aureus ATCC 25923 & 1 & 1 & 0.312 & 0.15 & 0.014 \\
E. coli ATCC 25922 & 2 & 2 & 0.625 & 0.6 & 0.005 \\
S. typhi ATCC 12225 & 2 & 1 & 0.156 & 0.075 & 0.010 \\
S. flexneri ATCC 12022 & 2 & 2 & 0.156 & 0.15 & 0.007 \\
V. cholera ATCC 39315 & 2 & 2 & 0.156 & 0.075 & 0.020 \\
\hline
\end{tabular}

*aq: Aqueous extract, et: Ethanolic extract, S. aureus: Staphylococcus aureus, E. coli: Escherichia coli, S. typhi: Salmonella typhi, S. flexneri: Shigella flexneri, V. cholera: Vibrio cholera, S. caryophyllatum: Syzygium caryophyllatum, TKA: Time-kill assay, MIC: Minimum inhibitory concentration

The phytochemical analysis confirmed the presence of flavonoids, alkaloids, glycosides, steroids, phenols, tannins, and saponins in the ethanolic and aqueous extract of $S$. caryophyllatum leaves. These phytochemicals confer antimicrobial activity on the leaf extracts. The various phytochemical compounds have proven for their beneficial importance in medicinal sciences. For instance, flavonoids have been referred to as nature's biological response modifiers, due to their inherent ability to modify the body's reaction to allergies, virus and they showed their anti-allergic, anti-inflammatory, antimicrobial, and anticancer activities [10]. Plant steroids are known to be important for their cardiotonic activities and also possess insecticidal and antimicrobial properties. They are also used in nutrition, herbal medicine, and cosmetics [11]. Tannins were reported to exhibit antiviral, antibacterial, and anti-tumor activities. It was also reported that certain tannins were used as diuretic [11]. Saponin is used as mild detergents and in intracellular histochemical staining. In medicine, it is used in hypercholesterolemia, hyperglycemia, cancer, inflammatory conditions, and it is also known to have antifungal properties [12]

\section{CONCLUSION}

Both aqueous and ethanolic extracts of $S$. caryophyllatum were exhibited antibacterial activity in small quantities against bacteria such as $S$. aureus, E. coli, S. typhi, S. flexneri, and V. cholerae. It may be a better and cheaper herbal alternative to antimicrobial agents. However, further studies are required to elucidate the role of $S$. caryophyllatum as a therapeutic agent.

\section{AUTHORS CONTRIBUTION}

\section{CONFLICTS OF INTERESTS}

None.

\section{REFERENCES}

1. Ediriweera ER, Ratnasooriya WD. A review on herbs used in treatment of diabetes mellitus by Sri Lankan ayurvedic and traditional physicians. Int Q J Res Ayurveda 2009;30:373.

2. Shilpa KJ, Krishnakumar G. leaf essential oil composition and biochemical activity of an endangered medicinal tree Syzygium caryophyllatum (L.) Alston, (Wild black plum). Int J Pharm Sci 2012;4:198.

3. Ratheesh NM, Anilkumar N, Balakrishnan V, Sivadasan M, Ahmed Alfarhan H, Alatar AA. Wild edible plants used by the kattanaikka, Paniya and Kuruma tribes of Waynad district, Kerala, India. J Med Plants Res 2011;5:3520

4. Ashton S, Mark S, Savitri G, Neela D, Nimal G, Dassanayake MD, et al. Field Guide Common Trees by Mark Ashton. Sri Lanka: The Wildlife Heritage Trust of Sri Lanka; 1997.

5. Alade PI, Irobi ON. Antimicrobial activities of crude leaf extracts of Acalypha wilkesiana. J Ethnopharmacol 1993;39:171-4.

6. Khandelwal KR. Practical Pharmacognosy Technique and Experiments, 
$2^{\text {nd }}$ ed. Pune: Nirali Prakashan; 2000. p. 149-56.

7. European Committee for Antimicrobial Susceptibility Testing (EUCAST) of the European Society of Clinical Microbiology and Infectious Dieases (ESCMID). EUCAST definitive document E.DEF 3.1, june 2000: Determination of minimum inhibitory concentrations (MICs) of antibacterial agents by agar dilution. Clin Microbiol Infect 2000;6:509-15.

8. Okoli S, Iroegbu CU. In vitro antibacterial activity of synclisa scabrida whole root extract. Afr J Biotechnol 2005:4:946-52.

9. EUCAST (European Committee for Antimicrobial Susceptibility
Testing). Determination of minimum inhibitory concentrations (MICs) of antibacterial agents by broth dilution. Clin Microbiol Infect 2003;9:1-7.

10. Aiyelaagbe OO, Osamudiamen PM. Phytochemical screening for active compounds in Mangifera indica, Plant. Sci Res 2009;2:11-3.

11. Callow RK. Relations between optical rotatory power and constitution in thesteroids. Proc Roy Soc London Ser A 1936;157:194.

12. Haslem E. Plant polyphenols: Vegetable tannins revisied-chemistry and pharmacology of natural products. Cambridge: Cambridge University Press; 1989. p. 169. 